\title{
PENGARUH KUALITAS PRODUK, FAKTOR PRIBADI, DAN FAKTOR SOSIALTERHADAP KEPUTUSAN PEMBELIAN KONSUMEN
}

\section{Puteri Andira, M. Rusyidi dan Chandra Zaki Maulana}

Universitas Islam Negeri Raden Fatah Palembang, Sumatera Selatan

Email: andiraputeri@yahoo.co.id,mrusydi@radenfatah.ac.id dan chandrazakimaulana@radenfatah.ac.id

\section{Abstract}

The purpose of this study was to determine how the influence of product quality, personal factors, and social factors simultaneously on consumer purchasing decisions at the PempekBeringin Shop, Palembang Trade Center Mall Branch. This data uses secondary data with document data collection methods. The results of this study are the influence of product quality on purchasing decisions: there is a positive effect of product quality on purchasing decisions: there is a positive influence of personal factors on purchasing decisions: there is a positive influence of social factors on purchasing decisions.

Keywords: product quality; personal factors; social factors; purchase decision

\section{Abstrak}

Tujuan penelitian ini untuk mengetahui bagaimana pengaruh kualitas produk, faktor pribadi, dan faktor sosial secara simultan terhadap keputusan pembelian konsumen pada Toko Pempek Beringin Cabang Palembang Trade Center Mall. Data ini menggunakan data sekunder dengan metode pengumpulan data dokumen. Hasil penelitian ini yaitu adanya pengaruh antara kualitas produk terhadap keputusan pembelian: adanya pengaruh positif kualitas produk terhadap keputusan pembelian: adanya pengaruh positif factor pribadi terhadap keputusan pembelian: adanya pengaruh positif factor sosial terhadap keputusan pembelian.

Kata Kunci: kualitas produk; faktor pribadi; faktor sosial; keputusan pembelian

\section{Pendahuluan}

Melihat besarnya potensi dari masyarakat yang mengkonsumsi pempek membuat banyak pengusaha tertarik untuk membuka usaha pempek. Usaha pempek yang sudahmenjamur di Kota Palembang membuat persaingan semakin ketat dan menuntut pengusaha untuk dapat bersaing dengan produk yang ditawarkan, semakin banyaknya pesaing makan semakin banyak pula pilihan bagi konsumen untuk dapat memilih produk yang sesuai harapannya.

Menurut (Sangadji \& Sopiah, 2013) Pengusaha harus dapat memenuhi kebutuhan dan keinginan konsumennya, serta pengusaha harus dapat mempengaruhi konsumen untuk melakukan pembelian. Schiffman dan Kanuk mendefinisikan bahwa keputusan

$\begin{array}{ll}\text { How to cite: } & \text { Andira, Puteri., et.al. (2021) Pengaruh Kualitas Produk, Faktor Pribadi, dan Faktor Sosial terhadap } \\ & \text { Keputusan Pembelian Konsumen. Syntax Literate: Jurnal IImiah Indonesia. 6(4). } \\ & \text { http://dx.doi.org/10.36418/syntax-literate.v6i4.2523 } \\ \text { E-ISSN: } & \text { 2548-1398 } \\ \text { Published by: } & \text { Ridwan Institute }\end{array}$


sebagai pemilihan suatu tindakan dari dua pilihan alternatif atau lebih. Seorang konsumen yang hendak memilih harus memiliki pilihan alternatif. Keputusan untuk membeli dapat mengarah pada bagaimana proses dalam pengambilan keputusan tersebut itu dilakukan.

Dapat dikatakan bahwa keputusan pembelian merupakan tahap akhir dimana konsumen akan membeli atau tidak dari setiap alternatif yang ada untuk memenuhi kebutuhannya. Hal tersebut sangat diperlukan oleh setiap perusahaan serta menjadi salah satu tolak ukur keberhasilan dari manajemen pemasaran yang bertujuan mempengaruhi konsumen untuk melakukan keputusan pembelian produk pada perusahaan tersebut.

Konsumen akan memilih produk makanan yang dibutuhkan dan diinginkan sebelum melakukan keputusan pembelian. Konsumen tentu ingin membelimakanan yang berkualitas dan mengharapkan adanya kesesuaian antara yang telah mereka bayarkan dengan kualitas produk yang mereka terima. Produk makanan, konsumen mengharapkan makanan yang tidak mengandung bahan pengawet, tercantumnya label dari BPOM (Badan Pengawas Obat dan Makanan) juga penting sebagai jaminan kepada konsumen bahwa produk yang akan dibeli adalah produk makanan yang aman untuk dikonsumsi.

Menurut (Wang, Hernandez, Minor, \& Wei, 2012) mendefinisikan kualitas produk sebagai evaluasi menyeluruh pelanggan atas kebaikan kinerja barang atau jasa. Sedangkan Kotler menyatakan bahwa kita dapa tmengatakan bahwa penjual telah menghasilkan mutu bila produk atau layanan penjual tersebut memenuhi atau melebihi harapan pelanggan. Selain kualitas produk, suatu perusahaan harus dapat memahami perilaku konsumennya agar dapat memenuhi kebutuhan dan keinginan konsumennya.

Menurut (Kotler \& Amstrong, 2018) menyatakan faktor-faktor yang mempengaruhi perilaku konsumen terdiri dari factor budaya, factor pribadi, dan factor sosial, dan factor psikologis. Faktor pribadi diartikan sebagai karakteristik yang adadalamdiriindividu yang melibatkan berbagai proses psikologis yang akan menentukan kecenderungan dan respon seseorang terhadap lingkungan. Fakto rpribadi juga di definisikan sebagai karakteristik psikologis seseorang yang berbeda dengan orang lain yang menyebabkan tanggapan yang relatif konsisten dan bertahan lama terhadap lingkungan.

Menurut (Ajzen, 2011),mengemukakan bahwa Theory of Planned Behavior telah muncul sebagai salah satu dari kerangka kerja yang paling berpengaruh dan konsep yang populer pada penelitian di bidang kemanusiaan. Teori ini berusaha untuk memprediksi dan menjelaskan perilaku manusia dalam konteks tertentu. Dalam teori perilaku terencana (Theory of Planned Behavior), faktor utama dari suatu perilaku yang ditampilkan individu adalah intensi untuk menampilkan perilaku tertentu. Karena berkaitan dengan perencanaan konsumen untuk membeli produk yang diperoleh dari informasi Pelanggan, kualitas produk. Faktor pribadi dan faktor sosial.

Penelitian oleh (Fernando \& Aksari, 2018) denganjudulPengaruhKualitasProduk, Harga, Promosi, dan DistribusiTerhadap Keputusan PembelianProduk Sanitary Ware Toto Di Kota Denpasar, bahwakualitasproduk, harga, promosi, dan distribusisecara 
parsial berpengaruh positif dan signifikan terhadap keputusan pembelian produk sanitary Ware Toto di Kota Denpasar.

Penelitian oleh (Pratiwi \& Mandala, 2015) dengan judul pengaruh faktor budaya, sosial, pribadi, psikologis dan bauran pemasaran terhadap keputusan pembelian kebaya bordir pada Jegeg Ayu Boutique di Kuta, hasil penelitian menunjukkan bahwa variabel factor budaya, sosial, pribadi, psikologis, dan bauran pemasaran berpengaruh positif signifikan terhadap keputusan pembelian kebaya bordir pada Jegeg Ayu Boutique di Kuta.

Penelitian oleh (A Azis,2018) dengan judul penelitian pengaruh faktor pribadi dan faktor sosial terhadap keputusan pembelian konsumen di Alfamart. Dalam penelitian ini diketahui bahwa faktor pribadi dan faktor sosial memiliki pengaruh dalam proses keputusan pembelian konsumen pada Alfamart, sehingga perusahaan harus mampu meningkatkan kedua faktor tersebut yang mampu mempengaruhi keputusan pembelian.

Penelitian oleh (Risa Ekawati, 2020) dengan judul pengaruh faktor budaya,sosial,pribadi, dan psikologis terhadap keputusan pembelian di Supermarket Sakinah Surabaya. Dalam penelitian ini secara simultan dan signifikan faktor budaya,sosail,pribadi dan psikologis berpengaruh terhadap keputusan pembelian di Supermarket sakinah Surabaya.

Penelitian oleh (Hailil Afida Ella, 2020) dengan judul pengaruh faktor budaya, sosial, pribadi dan psikologis terhadap keputusan pembelian Citra Hand and Body Lotion. Dalam penelitian ini variabel faktor budaya, sosial, pribadi dan psikologis berpengaruh secara signifikan terhadap keputusan pembelian Citra Hand and Body Lotian, sehingga terjadi peningkatan dalam permintaan konsumen.

Penelitian oleh (Michael Prayogo \& Liliani ,2017) dengan judul Pengaruh kualitas produk, harga dan faktor sosial terhadap keputusan pembelian bakso pepo. Pada penelitian ini menunjukan bahwa kualitas produk,harga dan faktor sosial memiliki pengaruh yang signifikan terhadap keputusan pembelian konsumen bakso pepo dan memiliki pengaruh positif terhadap terhadap keputusan pembelian.

Penelitian oleh (Supriyadi, Wahyu, Ginanjar, 2017) dengan judul pengaruh kualitas produk dan brand image terhadap keputusan pembelian. Dalam penelitian ini kualitas berpengaruh positif dan sginifikan terhadap keputusan pembelian, sedangkan brand image tidak berpengaruh terhadap keputusan pembelian.

Penelitian oleh (Andi Faisal Bahari, Muhammad Ashoer, 2018) dengan judul pengaruh budaya,sosial,pribadi dan psikologis terhadap keputusan pembelian konsumen ekowisata. Dalam penelitian ini menunjukkan bahwa pengaruh budaya,sosal,pribadi dan psikologis secara simultan dan parsial terhadap keputusan wisatawan berkunjung berpengaruh potif.

Penelitian oleh (RR. Abdullah, Edi Yulianto,M.Kholid, 2017) dengan judul pengaruh sikap,faktor pribadi dan faktor sosial terhadap keputusam pembelian (survey pada konsumen kartu perdana Malang). Dalam penelitian ini menunjukan bahwa 
terdapat pengaruh yang signifikan secara bersama-sama dari variabel sikap,faktor pribadi dan faktor sosial terhadap keputusan pembelian.

Penelitian oleh (Galih Aprilian, Nurul Qomariah, A Anwar, 2017) dengan judul Pengaruh faktor budaya, sosial, pribadi dan psikologis Terhadap Keputusan Pembelian di Café cangkir klasik Jember. Hasil dari penelitian ini menunjukan bahwa faktor budaya, sosial, pribadi dan psikologis berpengaruh signifikan secara parsial maupun secara simultan terhadap keputusan pembelian di café cangkir klasik Jember.

Penelitian oleh (Henni Noviasari dan Muhammad Aulia Ikram, 2017) yang berjudul pengaruh faktor sosial dan faktor pribadi terhadap keputusan pembelian kamera DSLR Canon di Kota pekanbaru. Hasil menunjukkan bahwa dari hasil perhitungan yang menggunakan regresi linear berganda dapat diketahui bahwa terdapat pengaruh yang signifikan positif antara variabel bebas $(\mathrm{X} 1=$ faktor sosial dan $\mathrm{X} 2=$ faktor pribadi) terhadap variabel terikat ( $\mathrm{Y}=$ keputusan pembelian).

Penelitian yang dilakukan oleh ( Yunita Sawitri, Wahyu Hidayat, dan Sendhang Nurseto, 2018) yang berjudul pengaruh kualitas produk, promosi, faktor sosial dan faktor psikologi terhadap keputusan pembelian sepeda motor matic yamaha mio. Hasil menunjukkan bahwa hasil analisis statistik diketahui persamaan regresi liniear sederhana antara kualitas produk dengan keputusan pembelian berpengaruh signifikan.

Penelitian oleh (Agung Suprayitno, Siti Rochaeni, dan Rahmi Purnomowati, 2019) yang berjudul pengaruh faktor budaya, sosial, pribadi, dan psikologi konsumen terhadap keputusan pembelian pada restoran gado-gado Boplo. Hasil menunjukkan bahwa variabel faktor budaya, sosial, pribadi, psikologi memiliki pengaruh nyata secara statistik terhadap keputusan pembelian konsumen di Restoran Gado-Gado Boplo dengan tingkat signifikansi 0,05 .

Penelitian oleh (Mercy, 2016) yang berjudul pengaruh faktor budaya, sosial, pribadi, dan psikologis terhadap keputusan pembelian handphone merek nokia di Kota Padang. sehingga dapat disimpulkan bahwa keempat variabel bebas secara simultan berpengaruh signifikan terhadap keputusan pembelian konsumen.

\section{Metode Penelitian}

Metode penelitian ini termasuk jenis penelitian kuantitatif. Penelitian kuantitatif adalah metode penelitian yang berlandaskan pada filsafat positivisme, digunakan untuk meneliti pada populasi atau sampel tertentu. Menurut (Sugiyono, 2016) Populasi adalah wilayah generalisasi yang terdiriatasobjekatausubjek yang mempunyaikualitas dan karakteristik tertentu yang ditetapkan oleh peneliti untuk dipelajari dan kemudian ditarik kesimpulannya. Populasi dalam penelitian ini adalah konsumen yang melakukan pembelian pempek pada Toko Pempek Beringin Cabang Palembang Trade Center Mall

Menurut (Sugiyono, 2016) Sampel adalah bagian darijumlah dan karakteristik yang dimiliki oleh populasitersebut. Sampel dalam penelitian ini adalah konsumen yang melakukan pembelian pada Toko Pempek Beringin Palembang Trade Center Mall.Teknik yang dilakukan dalam pengambilan sampel penelitian adalah teknik sampling insidental. 


\section{Hasil dan Pembahasan}

Tabel 1

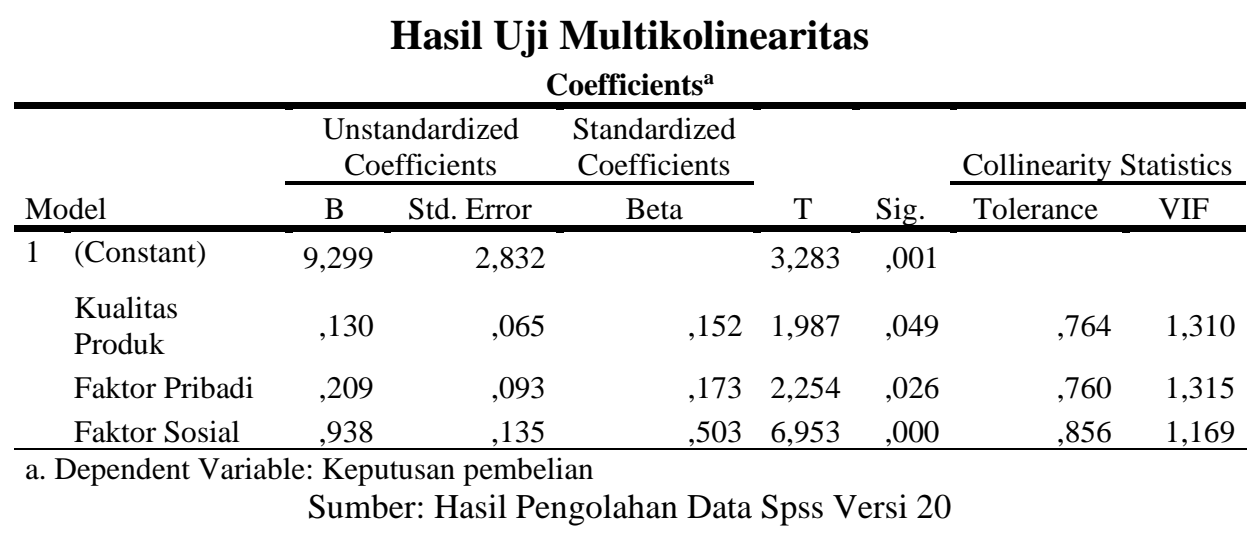

Berdasarkan tabel 1 dapat diketahui bahwa nilai tolerance variabel Kualitas Produk (X1), Faktor Pribadi (X2), dan Faktor Sosial (X3) lebih besar dari 0,10. Sementara itu, nilai VIF lebih kecil dari 10,00. Sehingga dapat disimpulkan tidak terjadi Multikolinearitas. Jadi kualitas produk, faktor pribadi dan faktor sosial berpengaruh terhadap keputusan pembelian.

Tabel 2

Hasil Analisis Regresi Linier Berganda Coefficients $^{\mathrm{a}}$

\begin{tabular}{|c|c|c|c|c|c|}
\hline \multirow[b]{2}{*}{ Model } & \multicolumn{2}{|c|}{ Unstandardized Coefficients } & \multirow{2}{*}{$\begin{array}{c}\text { Standardized } \\
\text { Coefficients } \\
\text { Beta }\end{array}$} & \multirow[b]{2}{*}{$\mathrm{T}$} & \multirow[b]{2}{*}{ Sig. } \\
\hline & B & Std. Error & & & \\
\hline $1 \quad$ (Constant) & 9,299 & 2,832 & & 3,283 & ,001 \\
\hline Kualitas Produk &, 130 &, 065 &, 152 & 1,987 & ,049 \\
\hline Faktor Pribadi & ,209 & ,093 & , 173 & 2,254 & ,026 \\
\hline Faktor Sosial & ,938 & 135 &, 503 & 6,953 &, 000 \\
\hline
\end{tabular}

a. Dependent Variable: Keputusan Pembelian

Sumber: Hasil Pengolahan Data Spss Versi 20

Berdasarkan tabel 2 dapat diketahui hasil analisis regresi linier berganda diatas, diperoleh persamaan regresi linier berganda masing-masing variabel dengan bantuan program SPSS Versi 20 yang dapat dirumuskan sebagai berikut:

$$
Y=9,299+0,130 X_{1}+0,209 X_{2}+0,938 X_{3}+e
$$

Dari hasil analisis regresi berganda di atas, dapat disimpulkan bahwa koefisien regresi variabel independen kualitas produk, faktor pribadi, dan faktor sosial diperoleh dengan tanda koefisien positif. Hal ini berarti bahwa variabel independen kualitas produk, faktor pribadi, dan faktor sosial mempengaruhi variabel dependen (keputusan pembelian konsumen pada Toko Pempek Beringin Cabang Palembang Trade Center Mall). 


\section{Tabel 3}

Hasil Uji T (Uji Parsial)

Coefficients $^{\mathrm{a}}$

\begin{tabular}{|c|c|c|c|c|c|c|}
\hline \multirow{2}{*}{\multicolumn{2}{|c|}{ Model }} & \multicolumn{2}{|c|}{$\begin{array}{c}\text { Unstandardized } \\
\text { Coefficients } \\
\end{array}$} & \multirow{2}{*}{$\begin{array}{c}\text { Standardized } \\
\text { Coefficients }\end{array}$} & \multirow[b]{2}{*}{$\mathrm{T}$} & \multirow[b]{2}{*}{ Sig. } \\
\hline & & $\mathrm{B}$ & Std. Error & & & \\
\hline \multirow[t]{4}{*}{1} & (Constant) & 9,299 & 2,832 & & 3,283 & ,001 \\
\hline & Kualitas Produk &, 130 &, 065 & , 152 & 1,987 & ,049 \\
\hline & Faktor Pribadi & ,209 & ,093 &, 173 & 2,254 & ,026 \\
\hline & Faktor Sosial & ,938 & ,135 &, 503 & 6,953 & ,000 \\
\hline
\end{tabular}

a. Dependent Variable: Keputusan Pembelian

Sumber: Hasil Pengolahan Data Spss Versi 20

Hasil analisis uji t adalahsebagaiberikut:

1) Dari tabel 4.20 dapat kita lihat bahwa nilai t hitung pada variabel kualitas produk adalah sebesar $(1,987)$ dengan tingkat signifikansi sebesar $(0,049)$. Karena nilai $t$ hitung lebih besa rdari t table yaitu $(1,987)>(1,978)$ dan nilai signifikansinya $(0,049)<(0,05)$, maka H0 ditolak dan Ha diterima. Hal ini berart bahwa variable kualitas produk berpengaruh positif dan signifikan terhadap keputusan pembelian konsumen.

2) Dari tabel 4.20 dapat kita lihat bahwa nilai t hitung pada variabel faktor pribadi adalah sebesar $(2,254)$ dengan tingkat signifikansi sebesar $(0,026)$. Karena nilai t hitung lebih besar dari $t$ table yaitu $(2,254)>(1,978)$ dan nilai signifikansinya $(0,026)<(0,05)$, maka H0 ditolak dan Ha diterima. Hal ini berarti bahwa variabel faktor pribadi berpengaruh positif dan signifikan terhadap keputusan pembelian konsumen.

3) Dari tabel 4.20 dapat kita lihat bahwa nilai t hitung pada variabel faktor sosial adalah sebesar $(6,953)$ dengan tingkat signifikansi sebesar $(0,000)$. Karena nilai $t$ hitung lebih besar dari t table yaitu $(6,953)>(1,978)$ dan nilai signifikansinya $(0,000)<(0,05)$, maka H0 ditolak dan Ha diterima. Hal ini berarti bahwa variabel faktor sosial berpengaruh positif dan signifikan terhadap keputusan pembelian konsumen.

Tabel 4

Hasil Uji F (Uji Simultan)

\begin{tabular}{lccccc}
\hline \multicolumn{5}{c}{ ANOVA $^{\mathbf{a}}$} \\
\hline Model & $\begin{array}{l}\text { Sum of } \\
\text { Squares }\end{array}$ & Df & Mean Square & F & Sig. \\
\hline Regression & $\mathbf{6 3 0 , 4 6 3}$ & $\mathbf{3}$ & $\mathbf{2 1 0 , 1 5 4}$ & $\mathbf{3 2 , 4 3 3}$ & $\mathbf{, 0 0 0}^{\mathbf{b}}$ \\
\hline Residual & $\mathbf{8 1 6 , 4 2 9}$ & $\mathbf{1 2 6}$ & $\mathbf{6 , 4 8 0}$ & & \\
\hline Total & $\mathbf{1 4 4 6 , 8 9 2}$ & $\mathbf{1 2 9}$ & & \\
\hline a. Dependent Variable: Keputusan Pembelian & \\
\hline b. Predictors: (Constant), Faktor Sosial, Kualitas Produk, Faktor \\
Pribadi
\end{tabular}

Sumber: Hasil Pengolahan Data Spss Versi 20 
Diketahui bahwa $F_{\text {tabel }}$ yaitu $(2,68)$, jadi berdasarkan tabel 4 bahwa nilai $F_{\text {hitung }}>F_{\text {tabel }}$ yaitu 32,433> 2,68 sehingga Ho ditolak dan Ha diterima dengan signifikansi sebesar $0,000<0,05$. Hal ini menunjukkan bahwa variabel kualitas produk (X1), faktor pribadi (X2), dan faktor sosial (X3) secara bersama-sama berpengaruh signifikan terhadap keputusan pembelian (Y).

H1 kualitas produkyang diberikanoleh Toko Pempek Beringin Cabang Palembang Trade Center Mall mempengaruhi keputusan pembelian. Variabel kualitas produk mempengaruhi keputusan pembelian pada dasarnya dikarenakan kualitas produk yang diberikan Toko Pempek Beringin sesuai dengan harapan konsumen seperti rasa nya yang pas lidah, pelayanan yang ramah, produk yang bisa dibawa keluar kota sebagai oleh-oleh, dan bisa menggunakan delivery untuk yang memesan seperti yang menginap di hotel.

H2faktor pribadi mempengaruhi keputusan pembelian konsumenpada Toko Pempek Beringin Cabang Palembang Trade Center Mall.Variabel faktor pribadi mempengaruhi keputusanpembelian konsumenpada Toko Pempek Beringin Cabang Palembang Trade Center Malldalam hal ini dikarenakanharga yang ditawarkan oleh Toko Pempek Beringin relatif terjangkau, sesuai dengan keadaan konsumen, dan minat konsumen.

H3 faktor sosial mempengaruhi keputusan pembelian konsumenpada Toko Pempek Beringin Cabang Palembang Trade Center Mall.Variabel faktor sosial mempengaruhi keputusanpembelian konsumenpada Toko Pempek Beringin Cabang Palembang Trade Center Malldalam hal ini dikarenakankonsumen mendapat rekomendasi makanan yang enak baik dari teman maupun keluarga yang sudah tahu dengan kualitas rasa atas pempek di Toko Pempek Beringin.

H4 kualitas produk, faktor pribadi, dan faktor sosial secara simultan mempengaruhi keputusan pembelian konsumenpada Toko Pempek Beringin Cabang Palembang Trade Center Mall.Hal ini dikarenakankualitas produk, faktor pribadi, dan faktor sosial pada Toko Pempek Beringin Cabang Palembang Trade Center Mall sudah baik dan sesuai harapan konsumen.

\section{Kesimpulan}

Pertama, terdapat pengaruh positif dan signifikan kualitas produk (X1) terhadap keputusan pembelian konsumen pada Toko Pempek Beringin Cabang Palembang Trade Center Mall (Y). Kualitas produk yang baik maka keputusan pembelian meningkat. Kedua, terdapat pengaruh positif dan signifikan faktor pribadi (X2) terhadap keputusan pembelian konsumen pada Toko Pempek Beringin Cabang Palembang Trade Center Mall (Y). Faktor pribadi yang baik maka keputusan pembelian meningkat.

Ketiga, terdapat pengaruh positif dan signifikan faktor sosial (X3) terhadap keputusan pembelian konsumen pada Toko Pempek Beringin Cabang Palembang Trade Center Mall (Y). Faktor Sosial yang baik maka keputusan pembelian akan meningkat. Empat, variabel kualitas produk, faktor pribadi, dan faktor sosial secara simultan 
Puteri Andira, M. Rusyidi dan Chandra Zaki Maulana

berpengaruh positif dan siginifikan terhadap keputusan pembelian konsumen pada Toko Pempek Beringin Cabang palembang Trade Center Mall. 


\section{BIBLIOGRAFI}

A. Azis. (2018). "pengaruh faktor pribadi dan faktor sosial terhadap keputusan pembelian konsumen di Alfamart, UIN-Alauddin" Google Scholar

Agung Suprayitno,dkk. "Pengaruh Faktor Budaya, Sosial, Pribadi, dan Psikologi Terhadap Keputusan Pembelian Pada restoran Gado-Gado Boplo", Jurnal Agribisnis, 2019. ISSN: 1979-0058. Vol 9 (2). Google Scholar

Ajzen, Icek. (2011). The theory of planned behaviour: Reactions and reflections. Taylor \& Francis. Google Scholar

Faisal Bahari, Muhammad Ashoer, (2018) "Pengaruh budaya,sosial,pribadi dan psikologis terhadap keputusan pembelian konsumen ekowisata, Vol.5, No.1 Jurnal Manajemen, Ide, Inspirasi (MINDS)”. Google Scholar

Fernando, Made Fajar, \& Aksari, Ni Made Asti. (2018). Pengaruh Kualitas Produk, Harga, Promosi, Dan Distribusi Terhadap Keputusan Pembelian Produk Sanitary Ware TOTO di Kota Denpasar. E-Jurnal Manajemen, 7(1), 441-469. Google Scholar

Galih Aprilian, Nurul Qomariah, A Anwar, (2017) "Pengaruh faktor budaya, sosial, pribadi dan psikologis Terhadap Keputusan Pembelian di Café cangkir klasik Jember, Vol.2, No.2, Jurnal Penelitian IPTEKS. Google Scholar

Hailil Afida Ella, (2020) "Pengaruh faktor budaya, sosial, pribadi dan psikologis terhadap keputusan pembelian Citra Hand and Body Lotion" Universiatas Jember. Google Scholar

Hendi Hakimi, "pengaruh faktor pribadi dan faktor psikologis terhadap keputusan pembelian konsumen di Kentucky Fried Chicken Singaraja”, Universitas Pendidikan Ganesha, Vol.5. No.1. 2015. Google Scholar

Henni Noviasari, Muhammad Aulia Ikram, "Pengaruh Faktor Sosial dan Faktor Pribadi Terhadap Keputusan Pembelian Kamera DSLR Canon di Kota Pekanbaru", Jurnal Sosial Ekonomi Pembangunan, 2017. Tahun III (9) Google Scholar

Kotler, Philip, \& Amstrong, Gary. (2018). Marekting Principle. Google Scholar

Mercy, "Pengaruh Faktor Budaya, Sosial, Pribadi, dan Psikologis Terhadap Keputusan Pembelian Handphone Merek Nokia di Kota Padang”, Journal of Economic and Economic Education, Vol.2, No.2, 2016, ISSN: 2302-1590. Google Scholar

Michael Prayogo \& Liliani ,(2017) "Pengaruh kualitas produk,harga dan faktor sosial terhadap keputusan pembelian bakso pepo, Vol.1,No.2,Jurnal Performa. Google Scholar 
Puteri Andira, M. Rusyidi dan Chandra Zaki Maulana

Pratiwi, Ketut Indah, \& Mandala, Kastawan. (2015). Pengaruh Faktor Budaya, Sosial, Pribadi, Psikologis, dan Bauran Pemasaran Terhadap Keputusan Pembelian Kebaya Bordir Pada Jegeg Ayu Boutique di Kuta. E-Jurnal Manajemen, 4(11). Google Scholar

RR.Abdullah, Edi Yulianto,M.Kholid,2017) "Pengaruh sikap,faktor pribadi dan faktor sosial terhadap keputusam pembelian (survey pada konsumen kartu perdana Malang) Vol.42, No.1, Jurnal Administrasi Bisnis”. Google Scholar

Sangadji, Etta Mamang, \& Sopiah. (2013). Perilaku Konsumen Pendekatan praktis disertai himpunan jurnal penelitian. C.V Andi Offset. Google Scholar

Sugiyono. (2016). Metode Penelitian Kuantitatif, Kualitatif, dan R\&D. Bandung: Alfabeta. Google Scholar

Supriyadi, Wahyu, Ginanjar, 2017) "Pengaruh kualitas produk dan Brand image terhadap keputusan pembelian, Vol.4, No.1, Jurnal Bisnis dan Manajemen". Google Scholar

Risa Ekawati, (2020) "Pengaruh faktor budaya, sosial, pribadi, dan psikologis terhadap keputusan pembelian di Supermarket Sakinah Surabaya” UIN Sunan Ampel. Google Scholar

Wang, Yong Jian, Hernandez, Monica D., Minor, Michael S., \& Wei, Jie. (2012). Superstitious beliefs in consumer evaluation of brand logos: Implications for corporate branding strategy. European Journal of Marketing. Google Scholar

Yunita Sawitri, dkk. "Pengaruh Kualitas Produk, Promosi, Faktor Sosial dan Faktor Psikologi Terhadap Keputusan Pembelian Sepeda Motor Matic Yamaha Mio", Diponegoro Journal Of Social and Politic, 2018. Google Scholar

\section{Copyright holder:}

Puteri Andira, M. Rusyidi dan Chandra Zaki Maulana (2021)

First publication right:

Journal Syntax Literate

This article is licensed under: 